Валентина Тасић

004.738.5:02

Универзитет у Београду

Филолошки факултет
371.3

https://doi.org/10.18485/filkult.2016.1.ch11

\title{
Дигиталне библиотеке у иновирању наставе
}

\section{Сажетак}

Развојем технологије, поједини библиотечки фондови постају лако доступни свим корисницима путем дигиталних библиотека. Разграничавањем појмова дигиталне библиотеке и библиотеке он-лајн, иде се ка ширем контексту и објашњењу шта данас представљају оба појма и на који начин корисници долазе до релевантних информација. У даљем тексту рад се бави употребом дигиталне библиотеке у иновирању наставе, пре свега наставе језика и књижевности. Дигитална библиотека представља не само национални него и међународни значај, где брз и једноставан приступ одређеним фондовима омогућава корисницима да пронађу потребну информацију.

На тај начин долази се до термина филологија, као и новог термина е-филологија. Наставак рада бави се примерима пројеката и збиркама дигиталних библиотека у нашој земљи, који се могу употребити у настави српског језика и књижевности. Пројекти као што су „Антологија српске књижевности“, „Растко“ и „Књиженство“ доводе до имплементације у настави српске књижевности где се фокус ставља на лаку и бесплатну доступност свим корисницима. Збирке дигиталних библиотека, с друге стране, представљају шири контекст од српске књижевности и могу се имплементирати у настави историје и географије, али и у настави страних језика.

Кључне речи: дигитална библиотека, е-филологија, пројекти, збирке, иновирање наставе, имплементација

\section{1. Ера технологије}

Почетком 80-их година, када је компанија IBM произвела први персонални рачунар, обележена је једна нова ера - ера технологије. Даљим развојем рачунара, и њихова све лакша доступност довела је до тога да данас свако од нас има код куће персонални рачунар или 
лаптоп. Самим тим, рачунари су ушли у примену процеса производње, постали су ослонац без којег је данас незамисливо. Тако су и културне институције попут библиотека, музеја и архива постале „зависне“ од рачунара. Библиотеке су пратиле технолошки развој и ишле су у корак са временом, те су тако увеле прво веб странице, а потом и електронске каталоге. „Запис у MARC-y јесте основа онлајн каталога и аутоматизованих система набавке и позајмице; без машински читљивих каталошких записа ми не бисмо имали онлајн каталоге" (Невил 26). На тај начин, све веће коришћење електронских каталога са појавом интернета, довело је до тога да се потисну лисни каталози и долази до њиховог избацивања. Сада тај простор који је заузимао лисни каталог замењен је са пар рачунара.

Библиотеке су полако постајале не само стециште знања, него и институције које су увек ту да пруже релевантну информацију корисницима и то 24 часа дневно. Њихова улога се није мењала већ се ширила са развојем технологије и самим тим постајала је свеобухватнија. За библиотеке је био највећи изазов како поставити одређени део фонда, он-лајн, односно да буде доступно свим корисницима који су заинтересовани за оне колекције, односно збирке, које су од културног и националног значаја једног народа, једног града. Дигитализацијом појединих библиотечких фондова, најчешће старе и ретке грађе, корисницима је омогућен удаљени приступ. Самим тим с једне стране чува се та стара и ретка грађа, пре свега због своје кртости и похабаности, а с друге стране, постаје доступна свима и омогућава њено шире коришћење. Полице са књигама различитог формата, различите структуре, са свим оштећењима, пресељавају се у један виртуелни свет где постају доступне свима широм света и на тај начин штеде не само у простору већ и у времену.

\section{2. Он-лајн и дигитална библиотека - разлике}

Пре него што се осврнемо на разлике између ова два појма потребно је разграничити њихове дефиниције. Са појавом World Wide Web-a, библиотеке откривају нови свет и постају лако доступне свима широм света. Интернет је учинио да се физичка библиотека пола- 
ко пресели у један нови, виртуелни свет. Библиотеке су направиле онлајн странице које су претраживе преко одређених Web прегледача. Дакле, он-лајн библиотека представља интернет страницу одређене библиотеке на којој се могу пронаћи информације везане за рад библиотеке, активности које библиотека организује односно дешавања у библиотеци, информацију о различитим пројектима као и о издањима одређених публикација. Све то дефинише он-лајн библиотеку и омогућава корисницима да путем електронског каталога виде да ли је одређена грађа доступна или није.

Дефиниција дигиталне библиотеке најбоље је објашњена у Манифесту за дигиталне библиотеке које је, као званични документ, уобличила IFLA. „Дигитална библиотека је збирка дигиталних објеката потврђеног квалитета доступна на вебу“(Ђукић и Трифуновић 66). Дигитална библиотека представља једну лаку доступност одређеном делу фонда библиотеке, било књиге или неког звучног записа, путем интернета. Тај фонд је читљив у различитим форматима, те тако одређена књига може бити приказана у обичном html формату, или пак, чешће у pdf формату.

Дигиталне колекције односно збирке, омогућавају кориснику приступ 24 часа недељно, без физичког одласка у библиотеку. Ова виртуелна библиотека отвара могућности да одређени садржај буде видљив свима, а не само појединим корисницима као што је то био случај са физичким библиотекама. На тај начин повезан је и однос он-лајн и дигиталне библиотеке, где је дигитална библиотека део онлајн библиотеке и њен основни задатак представља директан приступ одређеним збиркама. Тако на пример, можемо данас видети књигу из 13. или 14. века у дигиталном облику, а да не морамо да образлажем и попуњавамо одређене папире за коришћење ове изузетно вредне грађе која се чува у физичком облику у одређеним библиотекама.

Неке дигиталне библиотеке захтевају пријављивање, односно регистрацију корисника како би им одређена грађа била доступна. Такве дигиталне библиотеке имају за сврху пре свега заштиту од злоупотребе одређеног фонда, али и заштиту ауторских права. Разлике које се могу направити између он-лајн и дигиталне библиотеке су:

- дигитална библиотека пре свега омогућава корисницима коришћење фонда 24 часа дневно 
- он-лајн библиотека информише кориснике да ли је одређена грађа доступа

- он-лајн библиотека пружа информације о различитим дешавањима и активностима у библиотеци

- дигитална библиотека обезбеђује кориснику да од куће у различитим форматима приступи различитим фондовима у пуном запису

- дигитална библиотека има могућност да чува неограничени број публикација

На овај начин, можемо извести и све предности али и мане дигиталне библиотеке.

Предности дитигалне библиотеке су: лака доступност одређеној грађи, доступност 24 часа дневно, простор у односу на традиционалну физичку библиотеку, повратне информације односно претраживост одређених колекција или текста по кључним речима или фразама, дигитална библиотека чува и штити оштећену грађу али и грађу која би се похабала њеним сталним коришћењем. Мане дигиталних библиотека су: пријављивање корисника односно, давање одређених података како би се приступило комплетним дигиталним збиркама, стални развој софтвера ради побољшања услуга корисницима, немогућност да се трајно сачувају дигиталне колекције.

Дигитална библиотека представља не само национални, него и међународни значај, где брз и једноставан приступ одређеним фондовима омогућава корисницима да пронађу потребну информацију. Данас, свака национална библиотека нуди корисницима своје дигиталне збирке потпуно бесплатно. На тај начин, корисник распознаје одређени народ и његову културу у одређеном временском периоду. Полако се шири свест о очувању идентитета једнога народа, али и очувању тих истих колекција од њиховог прекомерног коришћења у физичком облику. Сведоци смо да је ера технологије променила доста тога.

Данас се технологија примењује не само у производним процесима, већ и у основним животним потребама, а једна од њих се посебно истиче - ширење знања односно, коришћење технологије у настави. Развојем информационе писмености и буђењем свести код људи да је технологија неопходна у одређеним животним потребама, долази се до закључка да нове генерације с лакоћом прихватају 
технологију и користе је у различите сврхе. Тако, те нове тзв. „нет“ генерације, примењују технологију и у учењу и на тај начин се и дигиталне библиотеке користе у настави. „Нет генерација подразумева популацију младих људи рођених после 1982. године а од претходних генерација се разликује првенствено по томе што расте уз персоналне раучнаре и интернет“ (Лазаревић 101). Употреба дигиталних библиотека у настави доводи до потпуног преокрета и једне нове иновације где ове генерације на брз и лак начин користе технолошка средства приликом учења или писања одређених радова.

\section{3. Филологија и е-филологија}

Доступност дигиталних колекција он-лајн омогућава бесплатно коришћење свим корисницима, пре свега ученицима и студентима, а целокупне дигиталне библиотеке примењују се и у иновирању наставе. Одређени фондови се могу применити пре свега у настави и проучавању одређеног језика и књижевности појединог народа. Неопходно је разграничити појмове као што су филологија и е-филологија, како би могли даље објаснити где се све могу применити дигиталне колекције у настави. Појам филологија потиче од грчке речи philologia која означава науку о одређеном језику, књижевности, старим писаним споменицима и народним обичајима. Она подразумева изучавање граматике, разумевање књижевних дела али и других текстова написаних на одређеном језику. Е-филологија представља изучавање одређеног језика и књижевности путем савремених технологија и путем интернета. Овај нови термин означава да се данас, у ери технологије и сталне иновације, језици одређених народа могу учити и без физичког одласка на часове. У било које доба, било где да се налазите језик који бисте желели да савладате, као и његова књижевност, данас су вам доступни путем интернета.

Примена дигиталних технологија у настави доводи до лакшег савладавања градива код ученика основних и средњих школа. Визуелизацијом, али и одређеним мултимедијалним садржајима, ученици лакше савладавају језичке баријере, а пре свега схватање одређеног књижевног дела или тежег текста. Поједини пројекти 
поспешују брже обраде одређених наставних јединица, али и лакше разумевање од стране ученика уз помоћ савремених технологија. На тај начин, самим тим и дигиталне библиотеке имају за циљ да пре свега, сваки њен корисник може неодређени број пута прегледати исту публикацију без бојазни да ће му та публикација бити недоступна у било којем тренутку.

\section{4. Употреба дигиталних библиотека у настави српског језика и књижевности}

Ширењем информационе писменост буди се свест код људи да могу размењивати информације и искуства путем различитих друштвених мрежа, али и на одређеним сајтовима. Међутим, проналазак релевантне информације понекад може да траје дуже него што смо мислили. Ту у помоћ прискачу различити пројекти који потпомажу да се на брз начин дође до релевантне информације. Помоћу дигиталних колекција, ученици данас могу лако доћи до одређеног књижевног дела. Раније, да би прочитали одређено књижевно дело које се обрађује у наставној јединици, било је потребно да ученик физички дође до библиотеке и наручио одређено књижевно дело. Уз мало више среће, књижевно дело ће добити и прочитати у одређеном временском периоду.

Међутим, често се дешавало да библиотеке не поседују довољан број примерака одређеног књижевног дела, те су ученици били приморавани да траже то дело у више библиотека. До овога је долазило, јер већина ученика истих разреда добије исти задатак по плану и програму како би за одређени временски период могли прочитати то дело и спремити га за наредне часове. Употреба дигиталних библиотека у настави српског језика и књижевности допринела би пре свега да сваки ученик приступи одређеном делу, али и да успешно обради анализу тог дела и тражене задатке који су везани за то дело. Наставници, поред школских и локалних библиотека треба да обрате пажњу и на дигиталне библиотеке, али и на пројекте који омогућавају лакше превазилажење тежег градива. Нове генерације савладавају технологију брже и самим тим су од малих ногу инфор- 
мационо писмени. Препоруком наставника, па и показивањем како да дођу до жељене информације долази се до иновирања наставе. Укључујући дигиталну технологију наставник показује да она помаже лакшем савладавању градива и бржем проналажењу задатих наставних јединица. Такође, успешност реализације одређене наставне јединице помоћиће и коришћење различитог мултимедијалног садржаја. Оно што је важно истаћи, јесу одређени пројекти који могу довести до имплементације у настави.

Часови српског језика и књижевности могу постати интересантнији свим ученицима уз правилно коришћење интернета и дигиталне технологије. С обзиром на то, да су нове „нет“ генерације информационо писмене, проналажење појединих релевантних информација им је лакше него раније. Помоћу различитих пројеката ученици имају лаку и брзу доступност књижевним делима, те на тај начин не морају физички одлазити по одређено дело у библиотекама. Пројекат „Антологија српске књижевности“ представља дигитализацију појединих дела из српске књижевности који се обрађују у настави српског језика и књижевности. Ова дигитализована библиотека бесплатно је доступна свим грађанима у Републици Србији и иностранству, и у функцији је промоције књижевних и културних добара у међународним оквирима, као и подизања књижевне, опште и дигиталне писмености грађана Републике Србије. Оно што је важно истаћи јесте да је овај пројекат рађен у оквиру програма „Партнер у учењу“ које је организовала компанија Мајкрософт, а одабир књижевних дела вршили су професори са Учитељског фаултета у Београду.

На почетној страни ове дигиталне библиотеке истичу се прозори који кориснику омогућавају лако сналажење. Ту су редом: азбучник дела, азбучник писаца, преглед дела по правцима, напредна претраживања и упутство за коришћење. Оно што истиче овај пројекат јесте да су сва дела бесплатна и да се могу преузети у сопствене сврхе без икаквог тражења информација од стране корисника. Сва књижевна дела су на ћирилици, што доказује потребу за очувањем писма српског језика. Подела дела по правцима, ученицима омогућава и разумевање одређеног периода када су та дела настала. На тај начин, наставник српског језика и књижевности, 
упућујући ученике на овај пројекат, ствара једну интерактивну атмосферу на часу.

Обрадом одређених одломака дела у читанци, наставник упућује, уколико је потребно да се прочита цело дело, на „Антологију српске књижевности". Писци који су обухваћени у овом пројекту су: Милутин Бојић, Јанко Веселиновић, Светлана Велмар-Јанковић, Милован Глишић, дечји писац Милован Данојлић, Јован Дучић, Радоје Домановић, Војислав Ђурић, Јаков Игњатовић, Ђура Јакшић, Стеван Јаковљевић, Јован Јовановић Змај, Лаза Костић, Петар Кочић, Момо Капор, Лаза К. Лазаревић, песникиња Десанка Максимовић, Симо Матавуљ, Момчило Настасијевић, наш прослављени комедиограф Бранислав Нушић, просветитељ Доситеј Обрадовић, сакупљач и реформатор Вук Стефановић Караџић, дечји писац Гроздана Олујић, Сима Пандуровић, Владислав Петковић Дис, Петар Петровић Његош, Растко Петровић, Васко Попа, Јован Стерија Поповић, Бранко Радичевић, Милан Ракић, Стеван Раичковић, Исидора Секулић, Стеван Сремац, Борисав Станковић, Бранко Ћопић, Добрица ћосић, Милош Црњански, Алекса Шантић. Из овог великог избора види се да је обухваћена настава српског језика и књижевности како за основне, тако и за средње школе. Наставник такође може упутити заинтересоване ученике, који желе нешто шире да читају од ових писаца, на страницу дигиталне библиотеке Народне библиотеке Србије где у колекцијама Библиотеке целине и легати могу пронаћи дела Милоша Црњанског, Књиге где се могу наћи дела Момчила Настасијевића, Борисава Станковића, Бранислава Нушића, Десанке Максимовић, а у оквиру саме колекције Књиге налази се и јако занимљива подзбирка Српска дечја дигитална библиотека где су разврстане дечје књиге за узраст до 13 година; затим у колекцији Стара и ретка књига налазе се дела Вука Стефановића Караџића, Бранка Радичевића, Јована Стерије Поповића, Доситеја Обрадовића, као и дела Петра Петровића Његоша.

Следећи пројекат који треба споменути настао је још давне 1997. године под називом „Растко“. Носећи име нашег просветитеља Светог Саве, овај пројекат представља један волонтерски подухват људи који су хтели да очувају српски језик, али и дела из различитих научних дисциплина. Пројекат Растко представља једну електронску библиотеку у којој су обухваћена дела из различитих науч- 
них дисциплина. Подељен је на науку и уметност, где под уметношћу стоји и књижевност. Књижевност је у овом пројекту подељена на усмену књижевност, литургичку књижевност, уметничку књижевност и на науку о књижевности. Овај пројекат је применљив за ученике средњих школа управо јер садржи доста дела који се могу наћи у наставном плану и програму за српски језик и књижевност предвиђен за средње школе.

Оно што је интересантно и раличито од пројекта „Антологије српске књижевности" јесте да су књиге у html формату, односно читљиве искључиво он-лајн. Усмена књижевност обухвата народну књижевност односно дела Вука Стефановића Караџића и његову сакупљачку делатност. Литургичка књижевност представља средњовековну књижевности и различита житија али и чланке који су везани за средњовековну књижевност. Уметничка књижевност садржи дела Петра Петровића Његоша, Растка Петровића као и Милорада Павића. Одељак наука о књижевности представља књиге и чланке који се баве проучавањем целокупне књижевности - од народне до савремене. Наставник српског језика и књижевности у средњој школи може навести овај пројекат као додатак литератури јер има доста занимљивих чланака који би помогли ученицима при разумевању појединих дела из усмене књижевности али и дела Петра Петровића Његоша, којег ученици често тешко савладавају.

Ове две дигиталне библиотеке, са применом у настави, могу се повезати са основном и средњом школом. У оквиру наставних програма, наставници имплементирају пројекте у иновирању њихове наставе. Самим тим, заинтересованост ученика расте и омогућује њихову интерактивну сарадњу са наставницима где их подстиче на размишљања и тумачења прочитаних текстова. Још један такав пројекат који би могао указати на заинтересованост ученика јесте „Књиженство“. Овај пројекат је настао 2011. године и представља женску књижевност на српском језику до 1915. године. Финансирање овог пројекта омогућило је Министарство просвете, науке и технологије. „Пројекат има за циљ да осветли историју женске књижевности на српском језику као и да теоретизује њене специфичности, преобликујући постојеће, углавном западне, појмове и моделе“ (Web 21.5.2016). Структура сајта је следећа: почетна стра- 
на, часопис, база података, архива, линкови и контакт. Како се овај пројекат бави проучавањем женске књижевности од средњега века до 1915. године, ту су обухваћене и књижевнице попут Исидоре Секулић, Милице Стојадиновић Српкиње, Мине Караџић Вукмановић, Милице Јанковић, монахиње Јефимије и многе друге. Сам часопис је електронског облика и садржи текстове данашњих истраживача и професора универзитета о познатим и мање познатим књижевницама. Треба истаћи да је сам пројекат повезан са COST акцијом IS0901 Women Writers in History: Toward a New Understanding of European Literary Culture, која обухвата базу података о европској женској књижевности до 1900. године Women Writers in History.

Посебан одељак односно прозор, јесте база података који се састоји од спискова: ауторке, радови, рецепција и серијске публикације. Ова база података под одељком ауторке садржи основне биографске и библиографске податке, да ли је ауторка имала псеудоним и интересантан одељак ауторке које је читала. Овај пројекат представља интересантну слику некадашњег живота на тлу данашње Србије и како су жене допринеле стварању једне непролазне књижевности. Наставници српског језика и књижевности могу показати овај пројекат ученицима, међутим мана му је та јер сви радови представљају само опис и информацију где се могу наћи, пошто су често то чланци из различитих серијских публикација. Како то опет доводи до једне недоступности, наставник само може да скрене пажњу ученицима да ту могу наћи тачне биографске и библиографске податке уместо да траже на другим електронским изворима.

Збирке дигиталних библиотека, с друге стране, представљају шири контекст од српске књижевности и могу се имплементирати у настави историје и географије, али и у настави страних језика. Тако, већина националних дигиталних библиотека пружа преглед националног културног блага, које проширује из дана у дан дигитализујући грађу коју поседује. Библиотечку грађу чини доступнијом и прегледнијом ширем броју корисника. Тако одређени путописи могу бити примењиви и у настави географије, али и у настави историје. Серијске публикације из времена великих ратова такође се могу примењивати у настави историје, стављајући фокус на одређени народ. На тај начин, дигитална библиотека потпомаже иновирању наставе и обезбеђује да се одређени временски периоди сачувају од заборава. 
Филологија културе

\section{Заључак}

Улога библиотека се није мењала временом, већ се ширила са развојем технологије и самим тим постајала је свеобухватнија. Дигитализацијом појединих библиотечких фондова, најчешће старе и ретке грађе, корисницима је омогућен удаљени приступ. Постављајући однос он-лајн и дигиталне библиотеке дошло се до закључка да је дигитална библиотека састав он-лајн библиотеке која омогућава корисницима широм света лаку и бесплатну доступност фондовима који су обележили један народ. Развојем технологије библиотеке преносе своје физичко место у виртуелни свет и самим тим постају повезане са корисницима путем различитих друштвених мрежа. Ширењем информационе писмености долази се до иновације у настави одређених предмета у основним и средњим школама. Пре свега, фокус се ставља на примену различитих дигиталних колекција у склопу наставе језика и књижевности. Разграничењем термина филологија и е-филологија даје се једна свеобухватна целина изучавања науке о језику.

Имплементирајући различите дигиталне библиотеке и пројекте у настави српског језика и књижевности, долази се до ширења свести да часови могу кренути у другом правцу - технолошко-иновативном. Пројекти попут Антологија српске књижевности и Растко, могу код ученика подстаћи један истраживачки дух. Користећи ове пројекте, наставник омогућава да ученик сагледа шароликост српске књижевности, али и лакше превазилажење градива. Успешност реализације одређене наставне јединице помоћиће и коришћење различитог мултимедијалног садржаја.

\section{Литература}

Ђукић Предраг и Богдан Трифуновић. „ИФЛА/УНЕСКО манифест за дигиталне библиотеке : српски превод“. Инфотека мај 2012: 65-68

Клајн Иван и Милан Шипка. Велики речник страних речи и израза. Нови Сад: Прометеј, 2012.

Невил, Гордон. „Развој дигиталних библиотека“. Инфотека 1-2 (2004): 25-33.

Лазаревић, Гордана. „Нет генерација и будућност библиотека“. Инфотека 1-2 (2006): 101-104. 
Crane, Gregory and David Bamman, Alison Jones. „ePhilology: When the Books Talk to Their Readers" Digital humanities Web 21 may 2016.

http://www.antologijasrpskeknjizevnosti.rs/ASK_sr_projekat.aspx. - преузето 21.5.2016.

http://www.rastko.rs/knjizevnost/ . - преузето 21.5.2016.

http://www.knjizenstvo.rs/. -преузето 21.5.2016.

\author{
Valentina Tasić \\ University of Belgrade \\ Facuulty of Phllogy
}

\title{
DIGITAL LIBRARIES IN INNOVATION OF TEACHING
}

\section{Summary}

With the development of technology, individual library resources are easily available to all users through digital libraries. Delimitation of the concepts of digital libraries and libraries on-line, goes to the broader context and explanation what today represent two concepts and how users reach relevant information. In the following, the work is concerned with the use of digital libraries in the innovation of teaching, especially teaching of language and literature. The digital library is not only a national but also international significance, where quick and easy access to certain resources allows users to find the necessary information.

In this way we come to terms philology, as well as the new term e-philology. Continuation of the work deals with examples of projects and collections of digital libraries in our country, which can be used in teaching Serbian language and literature. Projects such as "Anthology of Serbian Literature", "Rastko" and "Knjiženstvo" leads to implementation in Serbian literature classes where the focus is on the easy and free access to all users. Collections of digital libraries, on the other hand, represent the broader context of the Serbian literature and can be implemented in the teaching of history and geography, but also in foreign language classes.

Key words: digital library, e-philology, projects, collections, innovation of teaching, implementation 